\title{
Analyzing material flow and value added associated with non-metallic mineral wastes in Japan

\author{
Hasegawa Ryoji $1^{*}$, Hirofumi Nakayama² and Takayuki Shimoaka²
}

${ }^{*}$ Correspondence:
r-hasegawa@fcu.ac.jp
${ }^{1}$ Faculty of Urban
Management, Fukuyama
City University, 2-19-1,
Minatomachi, Fukuyama,
Hiroshima 721-0964, Japan
Full list of author information
is available at the end of the
article

*Correspondence: r-hasegawa@fcu.ac.jp ${ }^{1}$ Faculty of Urban City University, 2-19-1, Minatomachi, Fukuyama, Hiroshima 721-0964, Japan is available at the end of the

\begin{abstract}
This paper sheds light on the increase in generation of non-metallic mineral wastes and the decrease in demand for construction by investigating the material flow resulting from and the economic influence of changes in the supply and demand for wastes, focusing on the period from the near future to 2030. We predict the amount of final disposal of non-metallic mineral wastes and its influence on industries in the future under the assumption of two scenarios —zero emission and business-as-usual—using linear programming and input-output techniques developed for non-metallic mineral materials. We conclude that zero emission can be achieved at the cost of a 3.76\% decrease in the value added of industries related to non-metallic mineral wastes. Otherwise, the final disposal might increase 13 times the size of 2005's disposal. Considering the empirical results, we discuss an effective policy for non-metallic mineral waste management from the viewpoints of material flow and economic influence.
\end{abstract}

Keywords: Non-metallic mineral waste, Material flow, Balance of supply and demand, Linear programming, Input-output table

JEL Classification: Q50, Q53, C61, C67

\section{Background}

Rubble, slag, and sludge, referred to as non-metallic mineral wastes, are frequently recycled as alternate materials for natural non-metallic mineral resources such as dirt, crushed stone, sand, and clay. Concrete waste and asphalt concrete waste, which are non-metallic mineral wastes, are categorized as industrial wastes in Japan. According to the annual report of Japan's Ministry of the Environment (2015), the emission of these non-metallic mineral wastes in 2012 was 56.7 million tons in the country, which accounted for $15 \%$ of the 379.1 million tons of total industrial waste.

There are two emission sources of non-metallic mineral wastes: waste derived from demolishing existing stock, such as structures, and that generated as byproducts of industrial production. Specifically, concrete waste and asphalt generated from demolishing structures and repairing roads, respectively, are non-metallic mineral wastes derived from the demolition of existing stock. On the other hand, iron and steel slag and coal ash, derived from the steel industry and coal-fired power generation, respectively, are non-metallic mineral wastes generated as byproducts of production.

(c) The Author(s) 2017. This article is distributed under the terms of the Creative Commons Attribution 4.0 International License (http://creativecommons.org/licenses/by/4.0/), which permits unrestricted use, distribution, and reproduction in any medium, provided you give appropriate credit to the original author(s) and the source, provide a link to the Creative Commons license, and indicate if changes were made. 
On the supply side, considering the generation of non-metallic mineral wastes in the future in Japan, it is expected that concrete waste will continuously and drastically increase. In Japan, the stock of structures had been rapidly accumulated since the 1950s in accordance with high economic growth. Especially, the stock of non-timber structures, which is the main generation source of concrete waste, continued to increase at a higher ratio than that of timber structures every year, and the increasing trend was sustained until the 1990s (see e.g. Ministry of the Environment 2002).

The demolition of structures that have reached the end of their life has already begun to increase and is expected to accelerate in the future. Furthermore, because it is hard to imagine that steel production and coal-fired power generation will suddenly decrease, it is expected that the emission of non-metallic mineral wastes will continue to increase. Hashimoto et al. (2009), for example, estimated the stock of materials accumulated as structures in Japan and noted that 32 billion tons of materials were accumulated as construction commodities in 2000 , of which 9 billion tons are likely to be generated as waste in the future.

On the other hand, on the demand side, recycled non-metallic mineral wastes are primarily used in civil engineering and construction, such as base course and raw cement materials. The demand has begun to decrease due to the saturation of social infrastructures.

This phenomenon leads to the collapse of the balance of supply and demand in nonmetallic mineral wastes, which increases the amount of final disposal. While this phenomenon has already been detected in Japan, there is a high possibility that other Asian countries, which have achieved high economic growth, will also face a similar one in the future. It is crucial to establish appropriate waste management policies, particularly focusing on non-metallic mineral wastes, for sustainable development in the AsiaPacific region.

Therefore, it is significant to select Japan as the case study of non-metallic mineral wastes, because it provides useful implications for future waste policies in Asian countries. Furthermore, it is also significant that this paper, which targets the case study of Japan, is published as the Special Issue on "On the Nexus of Economy and Environment in the Asia-Pacific Region."

Based on the circumstances described above, this paper, considering the case of Japan, investigates the material flow resulting from and the economic influence of the changes in supply and demand for non-metallic mineral wastes, focusing on the period from the near future to 2030. Specifically, we construct an input-output (IO) table to analyze non-metallic mineral wastes to identify monetary and material flows between industries related to supply and demand in non-metallic mineral wastes. Based on the constructed IO table, we predict the material flow and value added brought about by non-metallic mineral wastes in the future by applying a linear programming technique.

The reminder of the paper is organized as follows. Section 2 explains supply and demand for non-metallic mineral wastes and the related industries covered in this paper. We also compile an IO table for the analysis of non-metallic mineral wastes. Section 3 develops a linear programming model to predict material flows and value added in 2030 . Section 4 investigates the empirical results. Finally, Sect. 5 summarizes the discussion and conclusion. 


\section{Material flow and industries related to non-metallic mineral wastes}

\subsection{Target materials and related industries}

Figure 1 shows the material flow covered in our analysis. As non-metallic mineral wastes, this paper targets (1) concrete waste, (2) asphalt concrete waste generated from both demolishing structures and repairing roads, (3) iron and steel slag generated as by-products in manufacturing steel, and (4) coal ash generated primarily from the coal power industry. We regard the generation of these four materials as supply and the use of these materials as demand. Application usages are defined as crushed stones for roads, aggregate for concrete, other crushed stones, asphalt mixture, and cement (raw material and admixture ingredient). What is not reused from the non-metallic mineral wastes generated will be disposed of as final disposal wastes.

\subsection{Input-output table for analysis of non-metallic mineral wastes}

This paper constructs an IO table for the analysis of non-metallic mineral wastes to comprehensively identify the material flow in non-metallic mineral wastes and the related monetary flow among industries. The IO model addressing environmental loads is generally established as the Leontif-Duchin environmental input-output (EIO) model (Leontief 1970; Duchin 1990). While a normal IO table allocates monetary transactions of goods and services among each sector, such as industry, household, and government,

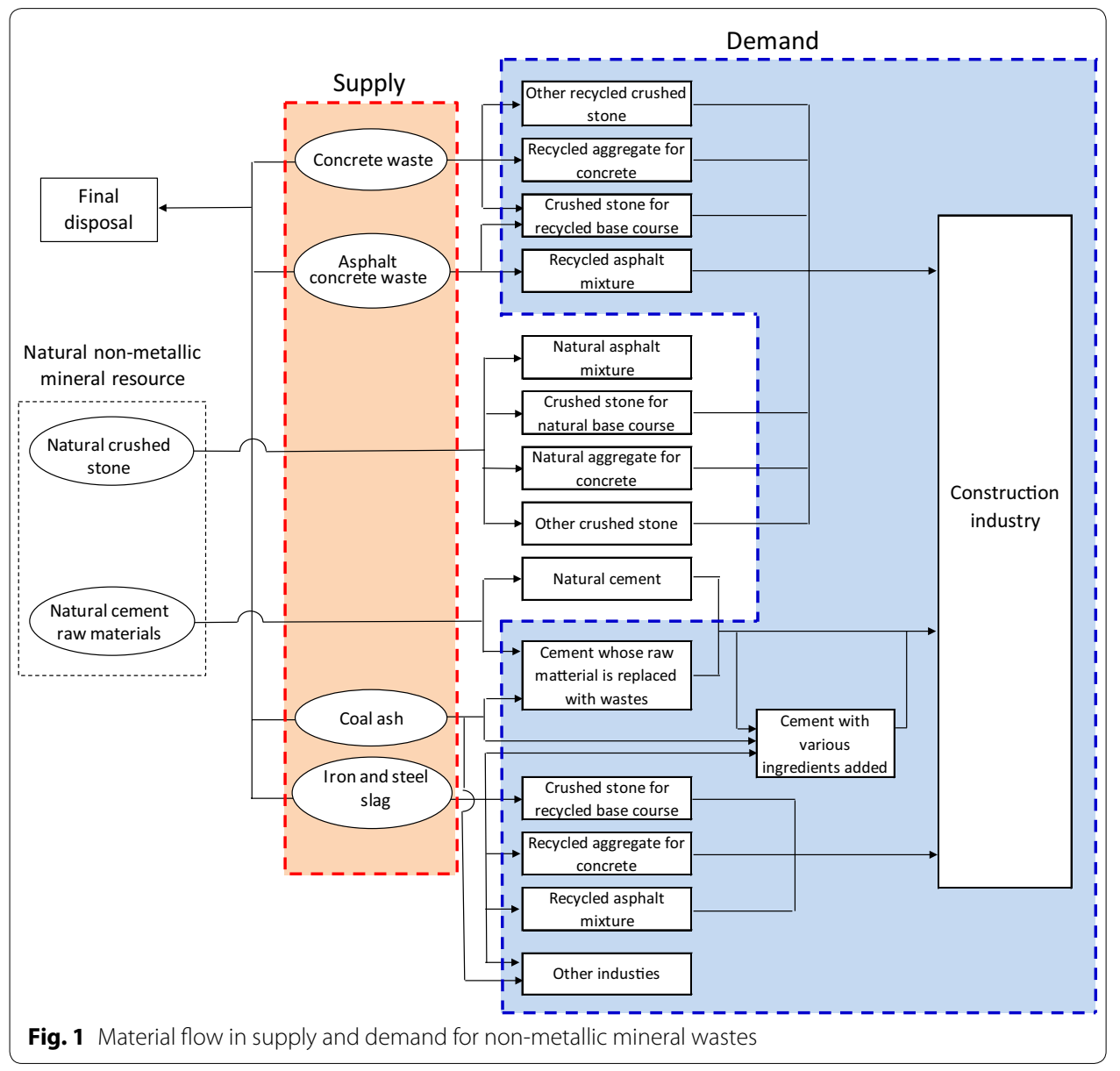


in the form of a matrix, EIO tables are frequently developed by expanding the scope of allocation to include environmental loads such as waste, energy, and air pollutant (see, e.g., Leontief 1970; Bullard and Herendeen 1975; Nakamura and Kondo 2002; Guan and Hubacek 2008). Focusing on application to waste analyses in the IO model, Nakamura and Kondo (2002) establish the waste input-output (WIO) model, which explicitly identifies the interdependence between the flow of goods and waste in the entire economy, and the model has been applied to many case studies (see, e.g., Kagawa 2005; Kagawa et al. 2007; Reynolds et al. 2014; Tsukui et al. 2015).

This paper compiles an IO table for non-metallic mineral wastes analysis based on the IO table in 2005 in Japan and other statistics. First, we modify the industrial classifications. Figure 2 shows the relationship between the classification in the original table and the compilation of classifications in the IO table for the analysis.

The industries involved in the supply of non-metallic mineral materials are crushed stones, paving materials, pig iron, crude steel, electric power for enterprise use, onsite power generation, and waste management services (private). We modify the input sector (column) in these industries according to the materials of non-metallic mineral resources, as shown in Table 1, because the production technology in non-metallic mineral resources varies according to the materials.

On the other hand, non-metallic mineral materials are demanded mainly for use as crushed stone for roads and concrete aggregate. Accordingly, the output of non-metallic mineral materials, classified by materials in input sectors (column), is integrated to crushed stone for roads, concrete aggregate, and other crushed stone as shown in Fig. 2. ${ }^{1}$

To modify the industrial classifications in the IO table, we first estimate the monetary production value of each non-metallic mineral material by identifying material outputs, prices, mass/volume, and main sale destinations from several statistical sources, such as Ministry of Economy, Trade and Industry (2005) and Nippon Slag Association (2005).

In the input sector (column), it is possible to separate recycled crushed stone for roads and recycled concrete aggregate from waste management services (private), and recycled asphalt mixture from paving materials, according to further detailed materials by using several statistics. We further divide these three industries in the output sector (row), as shown in Table 1. In Table 1, non-metallic mineral wastes generated by these three industries include concrete waste, asphalt concrete waste, iron and steel slag, and coal ash. These wastes are disposed of in different ways. This is why the three aforementioned industries are divided according to the production process. Concretely, we divide the monetary production value in these three industries using the ratio of the volume of input in each non-metallic mineral waste according to the materials shown in Table 1.

As shown in Table 2, conclusively, the classification number is nine in the output sector (row) and 20 in the input sector (column) among industries related to non-metallic mineral wastes, and the other industries consist of 33 sectors. A point to be noted here is that the other industries are not aggregated but divided by 33 sectors in the IO table and the classification completely corresponds to both the input and output sectors. Table 3 shows the classification in the 33 other industries. Accordingly, the constructed IO table

${ }^{1}$ In the output sector, some other sectors are also integrated to facilitate the linear programming. 


\begin{tabular}{|c|c|c|}
\hline $\begin{array}{l}\text { Detailed sector classification in } \\
\text { the original table in Japan }\end{array}$ & $\begin{array}{l}\text { Input sector (Column) in the } \\
\text { constructed IO table }\end{array}$ & $\begin{array}{l}\text { Output sector (Row) in the } \\
\text { constructed IO table }\end{array}$ \\
\hline \multirow[t]{3}{*}{ Crushed stones } & Natural crushed stones & Crushed stones for roads \\
\hline & Naturel concrete aggregate & Concrete aggregate \\
\hline & Other crushed stones & Other crushed stones \\
\hline \multirow[t]{2}{*}{ Paving materials } & Natural asphalt mixture & \multirow[t]{2}{*}{ Asphalt mixture } \\
\hline & Recycled asphalt mixture & \\
\hline Cement & Cement & \multirow[t]{3}{*}{ Cement/cement products } \\
\hline Ready mixed concrete & Ready mixed concrete & \\
\hline Cement products & Cement products & \\
\hline Pig iron & \multirow[t]{3}{*}{ Pig iron/crude steel } & \multirow[t]{3}{*}{ Pig iron/crude steel } \\
\hline Crude steel (converters) & & \\
\hline Crude steel (electric furnaces) & & \\
\hline Repair of construction & Repair of construction & \multirow[t]{12}{*}{ Construction } \\
\hline Public construction of roads & Public construction of roads & \\
\hline $\begin{array}{l}\text { Residential construction } \\
\text { (wooden) }\end{array}$ & \multirow[t]{10}{*}{$\begin{array}{l}\text { Other civil engineering and } \\
\text { construction }\end{array}$} & \\
\hline $\begin{array}{l}\text { Residential construction } \\
\text { (non-wooden) }\end{array}$ & & \\
\hline $\begin{array}{l}\text { Non-residential construction } \\
\text { (wooden) }\end{array}$ & & \\
\hline $\begin{array}{l}\text { Non-residential construction } \\
\text { (non-wooden) }\end{array}$ & & \\
\hline $\begin{array}{l}\text { Public construction of rivers, } \\
\text { drainages, and others }\end{array}$ & & \\
\hline Agricultural public construction & & \\
\hline Railway construction & & \\
\hline $\begin{array}{l}\text { Electric power facilities } \\
\text { construction }\end{array}$ & & \\
\hline $\begin{array}{l}\text { Telecommunication facilities } \\
\text { construction }\end{array}$ & & \\
\hline $\begin{array}{l}\text { Other civil engineering and } \\
\text { construction }\end{array}$ & & \\
\hline Electric power for enterprise use & \multirow{4}{*}{$\begin{array}{l}\text { Electric power, gas supply, and } \\
\text { steam and hot water supply }\end{array}$} & \multirow{4}{*}{$\begin{array}{l}\text { Electric power, gas supply, and } \\
\text { steam and hot water supply }\end{array}$} \\
\hline On-site power generation & & \\
\hline \multirow{2}{*}{$\begin{array}{l}\text { Gas supply } \\
\text { Steam and hot water supply }\end{array}$} & & \\
\hline & & \\
\hline $\begin{array}{l}\text { Waste management services } \\
\text { (public) }\end{array}$ & $\begin{array}{l}\text { Waste management services } \\
\text { (public) }\end{array}$ & $\begin{array}{l}\text { Waste management services } \\
\text { (public) }\end{array}$ \\
\hline \multirow{4}{*}{$\begin{array}{l}\text { Waste management services } \\
\text { (private) }\end{array}$} & Recycled crushed stones for roads & \\
\hline & Recycled concrete aggregate & \\
\hline & Other recycled crushed stones & \\
\hline & $\begin{array}{l}\text { Other waste management services } \\
\text { (private) }\end{array}$ & $\begin{array}{l}\text { Other waste management services } \\
\text { (private) }\end{array}$ \\
\hline Other industries & Other industries & Other industries \\
\hline
\end{tabular}

Table 1 Further classification of non-metallic mineral waste sectors

\begin{tabular}{ll}
\hline Further classification & Raw material \\
\hline Recycled crushed stones for roads 1 & Concrete waste, asphalt concrete waste \\
Recycled crushed stones for roads 2 & Iron and steel slag \\
Recycled concrete aggregate 1 & Concrete waste \\
Recycled concrete aggregate 2 & Iron and steel slag \\
Recycled asphalt mixture 1 & Concrete waste, asphalt concrete waste \\
Recycled asphalt mixture 2 & Iron and steel slag \\
\hline
\end{tabular}


Table 2 Industrial classification in the 10 table for analysis of non-metallic mineral wastes

\begin{tabular}{|c|c|}
\hline Input sector (column) & Output sector (row) \\
\hline \multicolumn{2}{|l|}{ Industry related to non-metallic mineral wastes } \\
\hline 1-1. Natural crushed stones & 1. Crushed stones for roads \\
\hline \multicolumn{2}{|l|}{ 1-2. Recycled crushed stones for roads 1} \\
\hline \multicolumn{2}{|l|}{ 1-3. Recycled crushed stones for roads 2} \\
\hline 2-1. Natural concrete aggregate & 2. Concrete aggregate \\
\hline \multicolumn{2}{|l|}{ 2-2. Recycled concrete aggregate 1} \\
\hline \multicolumn{2}{|l|}{ 2-3. Recycled concrete aggregate 2} \\
\hline 3-1. Other crushed stones & 3. Other crushed stones \\
\hline \multicolumn{2}{|l|}{ 3-2. Other recycled crushed stones } \\
\hline 4-1. Natural asphalt mixture & 4. Asphalt mixture \\
\hline \multicolumn{2}{|l|}{ 4-2. Recycled asphalt mixture 1} \\
\hline \multicolumn{2}{|l|}{ 4-3. Recycled asphalt mixture 2} \\
\hline 5-1. Cement & 5. Cement/cement products \\
\hline \multicolumn{2}{|l|}{ 5-2. Ready mixed concrete } \\
\hline \multicolumn{2}{|l|}{ 5-3. Cement products } \\
\hline 6. Pig iron/crude steel & 6. Pig iron/crude steel \\
\hline 7. Other iron and steel & 7. Other iron and steel \\
\hline 8-1. Repair of construction & 8. Construction \\
\hline \multicolumn{2}{|l|}{ 8-2. Public construction of roads } \\
\hline \multicolumn{2}{|l|}{ 8-3. Other civil engineering and construction } \\
\hline $\begin{array}{l}\text { 9. Electric power, gas supply and steam and hot water } \\
\text { supply }\end{array}$ & $\begin{array}{l}\text { 9. Electric power, gas supply, and steam and hot water } \\
\text { supply }\end{array}$ \\
\hline Other industries (33 sectors) & Other industries (33 sectors) \\
\hline
\end{tabular}

for analysis of non-metallic mineral wastes consists of 42 output sectors and 53 input sectors.

Regarding industries related to non-metallic mineral wastes, it is impossible to completely identify intermediate transactions from available statistics. Therefore, we estimate those transactions by applying the RAS method to accomplish the construction of the IO table. The RAS method, the most widely-used method to estimate input coefficients, estimates unknown matrices to approximate available input coefficient matrices by using the summations of rows and columns in the IO table as control totals. In applying the RAS method, we use production values as control totals and input coefficients based on the aforementioned statistics as initial values (see, e.g., Miller and Blair 2009) for the outline of the RAS method and the calculation procedure).

\section{Prediction of non-metallic mineral wastes in $\mathbf{2 0 3 0}$ via the linear programming method}

3.1 Japanese economy and non-metallic mineral wastes in $\mathbf{2 0 3 0}$

As noted in the introduction, the demand for construction is anticipated to decrease in the future, and it has been on a downward trend in recent years. For instance, the Research Institute of Construction and Economy (RICE) in Japan forecasts construction investment in Japan in the present year and next year every 3 months, and publishes the 
Table 3 Classification of the 33 other industries

\begin{tabular}{|c|c|c|c|c|c|}
\hline 10 & $\begin{array}{l}\text { Agriculture, forestry, and } \\
\text { fisheries }\end{array}$ & 21 & Electrical equipment & 32 & Real estate \\
\hline 11 & Other mining & 22 & $\begin{array}{l}\text { Information and communica- } \\
\text { tion equipment }\end{array}$ & 33 & Transport \\
\hline 12 & Food, beverage, and tobacco & 23 & Electrical equipment & 34 & $\begin{array}{l}\text { Communication and broad- } \\
\text { casting }\end{array}$ \\
\hline 13 & Textiles & 24 & Transport equipment & 35 & Public administration \\
\hline 14 & $\begin{array}{l}\text { Pulp, paper, and wooden } \\
\text { products }\end{array}$ & 25 & Precision machinery & 36 & Education and research \\
\hline 15 & Chemical products & 26 & $\begin{array}{l}\text { Miscellaneous manufacturing } \\
\text { products }\end{array}$ & 37 & $\begin{array}{l}\text { Medical service, health, social } \\
\text { security, and nursing service }\end{array}$ \\
\hline 16 & Petroleum refinery and coal & 27 & Water supply & 38 & Other public services \\
\hline 17 & $\begin{array}{l}\text { Miscellaneous ceramic, stone, } \\
\text { and clay products }\end{array}$ & 28 & $\begin{array}{l}\text { Waste management services } \\
\text { (public) }\end{array}$ & 39 & Business services \\
\hline 18 & Non-ferrous metal & 29 & $\begin{array}{l}\text { Other waste management } \\
\text { services (private) }\end{array}$ & 40 & Personal services \\
\hline 19 & Metal products & 30 & Trade & 41 & Office supplies \\
\hline 20 & General machinery & 31 & Finance and insurance & 42 & $\begin{array}{l}\text { Activities not elsewhere clas- } \\
\text { sified }\end{array}$ \\
\hline
\end{tabular}

The classification numbers follow that of industry related to non-metallic mineral wastes in Table 2

forecast results several times a year. ${ }^{2}$ Considering the forecasts, this paper assumes that the final demand in the construction sector declines at an annual rate of $1.1 \%$ from 2012 to 2020 based on figures in the IO table in 2011, and will remain constant from 2021 to 2030. Accordingly, the final demand in the construction sector is assumed to decrease to around 38.7 trillion yen, as shown in Table 4. RICE conducts middle- and long-range forecast for construction investment, and publishes them in Research Institute of Construction and Economy (2016). The report forecasts construction investment in 2030 to range from 37.5 to 43.4 trillion yen. Therefore, our decile rate has validity to some extent because the estimated value is within the range.

The final demand ${ }^{3}$ for crushed stones for roads, concrete aggregate, other crushed stones, asphalt mixture and cement/cement products is expected to decrease, influenced by construction's trend. Accordingly, this paper assumes that the final demand in these sectors declines at an annual rate of 1.1\% from 2011 to 2020 and remains constant from 2021 to 2030; however, the decline rate of 1.5\% is used from 2005 to 2010 for sectors in which the amount of final demand cannot be identified from the IO table in 2011.

Regarding the total economy, based on figures in the IO table in 2011, the total GDP of Japan is assumed to grow at a rate of 0.6, 0.9, 0.5, and $0 \%$ from 2011 to 2015,2016 to 2020, 2021 to 2025 , and 2026 to 2030 , respectively. ${ }^{4}$

In the prediction of non-metallic mineral wastes, the generation of concrete waste and asphalt concrete waste in the future is independent of production levels at that time,

\footnotetext{
2 The forecast results are available from the website of the Research Institute of Construction and Economy (RICE), shown in http://www.rice.or.jp/english/index.html.

3 The products in some industries related to non-metallic mineral wastes are entirely demanded as intermediate goods, but the final demand in this paper and in the IO table includes changes in stocks, exports, and imports.

4 To obtain the figures, we referred to the medium-term economic forecast by the Japan Center for Economic Research, as shown in https://www.jcer.or.jp/research/middle/index.html.
} 
Table 4 Actual values in $\mathbf{2 0 0 5}$ and predicted values in 2030

\begin{tabular}{llc}
\hline & $\mathbf{2 0 0 5}$ & $\mathbf{2 0 3 0}$ \\
\hline GDP in the total economy (billion yen) & $505,874,396$ \\
Final demand in industry related to non-metallic mineral wastes (million yen) & 19,269 & 16,323 \\
1 Crushed stones for roads & 3971 & 3364 \\
2 Concrete aggregate & -6665 & -7854 \\
3 Other crushed stones & 984 & 788 \\
4 Asphalt mixture & 11,293 & -4043 \\
5 Cement/cement products & $-459,734$ & $-481,074$ \\
6 Pig iron/crude steel & $2,283,700$ & $2,389,704$ \\
7 Other iron and steel & $54,117,611$ & $38,691,354$ \\
8 Construction & $5,923,813$ & $6,198,781$ \\
9 Electric power, gas supply, and steam and hot water supply & & 5,153 \\
Generation of non-metallic mineral waste (1000 ton) & 26,060 & 54,780 \\
Concrete waste & 40,450 & 17,270 \\
Asphalt concrete waste & 11,152 & - \\
Iron and steel slag & - \\
Coal ash & & -
\end{tabular}

because they are generated from both demolishing structures and repairing roads, in contrast to iron and steel slag and coal ash.

For concrete waste and asphalt concrete waste it is assumed that the trend from the actual value in 2005 to the value in 2020 predicted by the Ministry of Land, Infrastructure, Transport and Tourism ${ }^{5}$ in Japan will continue after 2020. On the other hand, the generation of iron and steel slag and coal ash in 2030 is endogenously determined to be dependent on the production value estimated by linear programming.

Table 4 summarizes our assumption of the economy and non-metallic mineral wastes in 2030, compared to the actual values in 2005.

\subsection{Linear programming model for non-metallic mineral wastes in $\mathbf{2 0 3 0}$}

Many studies use the linear programming technique to propose an optimal solution for waste management or recycling policy (see e.g., Gnoni et al. 2008; Zhu and Huang 2011; Song et al. 2016). Especially, linear programming models tend to be constructed based on IO tables when the supply and demand balance in monetary production value or the material flow balance in the entire economy are used as constraint conditions. For instance, Kondo and Nakamura (2005) develop the WIO-LP model, which links an ordinal WIO model to the linear programming model, to propose a systematic method for eco-efficiency analysis.

Using the IO table for the analysis of non-metallic mineral wastes, this paper applies a linear programming technique to consider the material flow and value added brought about by non-metallic mineral wastes in 2030.

\footnotetext{
${ }^{5}$ To obtain the figures, we referred to the forecast of construction waste generation of the Ministry of Land, Infrastructure, Transport and Tourism, shown at http://www.mlit.go.jp/sogoseisaku/region/recycle/pdf/fukusanbutsu/genjo/ yosoku.pdf.
} 
Although the constructed IO table comprehensively identify monetary transactions between industries related to non-metallic mineral wastes, it is not enough to use it within the IO framework in order to consider not only monetary transactions but the material flow representing the relationship between the generation, input, and final disposal. On the other hand, a linear programming technique can compatibly combine the material flow with monetary transactions by appropriately setting constraint conditions. Furthermore, it can predict the status in the entire economy in the future under the assumption of different scenarios to be aimed. Therefore, it is useful for our analysis to apply linear programming technique based on the constructed IO table.

First, we set the supply and demand equilibrium formulae in the goods and services production sector and the waste sector of each industry as a constraint condition. These constraint formulae are given, respectively, as follows:

$$
\begin{aligned}
& \mathbf{X}=\mathbf{A}_{1} \mathbf{X}+\mathbf{F} \\
& \mathbf{W}+\mathbf{A}_{2} \mathbf{X}-\mathbf{A}_{3} \mathbf{X}=\mathbf{L}
\end{aligned}
$$

Equation (1) is the balance equation in the IO model representing supply and demand equilibrium in goods and services production in the total economy. Here, $\mathbf{X}, \mathbf{A}_{1}$, and $\mathbf{F}$ represent production value, the technical coefficient, and final demand including imports and exports, respectively.

Equation (2) represents the relationship between the generation, input, and final disposal of non-metallic mineral wastes. $\mathbf{W}$ is the amount of generated concrete waste and asphalt concrete waste. The actual values are 54,780 thousand tons (concrete waste) and 17,270 thousand tons (asphalt concrete waste), which are regarded as constant, because these wastes are generated independently of the production value $(\mathbf{X})$. On the other hand, the generation of iron and steel slag and coal ash is represented as $\mathbf{A}_{2} \mathbf{X}$, where $\mathbf{A}_{2}$ is the generation coefficient indicating the amount of waste generated by one unit of production. $\mathbf{A}_{3}$ is the waste input coefficient indicating recycled wastes input by one unit of production. Therefore, $\mathbf{A}_{3} \mathbf{X}$ represents the amount of all non-metallic mineral wastes recycled in each industry.

As a constraint condition, we assume that the amount of input of wastes does not exceed the generated waste; in other words, final disposal $(\mathbf{L})$ is not negative. Therefore, Eq. (2) is rewritten as the actual constraint formulae as shown in (3). Furthermore, we set a non-negative condition of production value $(\mathbf{X})$ as shown in Eq. (4).

$$
\begin{aligned}
& 54780+17270+\mathbf{A}_{2} \mathbf{X}-\mathbf{A}_{3} \mathbf{X} \geq 0 \\
& \mathbf{X} \geq \mathbf{0}
\end{aligned}
$$

Second, we set target functions that represent policy targets. We set two target functions, as shown in Eqs. (5) and (6).

$$
\max _{x} \sum_{j=1} v_{j} x_{j}
$$

$\min _{x} \mathbf{L}$ 
In Eq. (5), $v_{j}$ and $x_{j}$, respectively, represent the value added coefficient and production value in industries related to non-metallic mineral wastes, respectively, as shown in Tables 2 and 4. Therefore, the target function in Eq. (5) represents the maximization of value added in industries related to non-metallic mineral wastes. This situation can be regarded as a business-as-usual (BAU) scenario, where industries are assumed to engage in ordinal activities as private producers without reduction policies for wastes increasing in 2030 .

On the other hand, Eq. (6) represents the minimization of final disposal of non-metallic mineral wastes, which can be regarded as a zero-emission scenario. This scenario assumes that production activities are encouraged to decrease final disposal of wastes to promote a recycling-oriented society.

For simplification, all coefficients of $\mathbf{A}_{1}, \mathbf{A}_{2}, \mathbf{A}_{3}$, and $v_{j}$ are assumed to be constant during the period from 2005 to 2030 . Although it is ideally desirable to predict these coefficients in the future, it is almost impossible due to lack of statistics and literature. Examining the trends of these coefficients in the past several years by investigating Ministry of Economy, Trade and Industry (2005) and Nippon Slag Association (2005), we can find that they have not changed significantly. Furthermore, the assumption of constants in the coefficients more directly reveals the influences brought about by the collapse of balance of supply and demand for non-metallic mineral wastes, which is the main focus of this paper.

\section{Empirical results}

\subsection{Material flow of non-metallic mineral wastes in $\mathbf{2 0 3 0}$}

First, in Figs. 3, 4, and 5, we investigate the different material flows resulting from the two scenarios, comparing them to that of 2005. Regarding the generation of concrete waste and asphalt concrete waste, which is determined independently of production values at the time, the former increases and the latter decreases based on our assumption, as summarized in Table 4. The generation of iron and steel slag and coal ash does not change significantly from 2005 to 2030 in these two scenarios, although it is determined dependent on production values at that time.

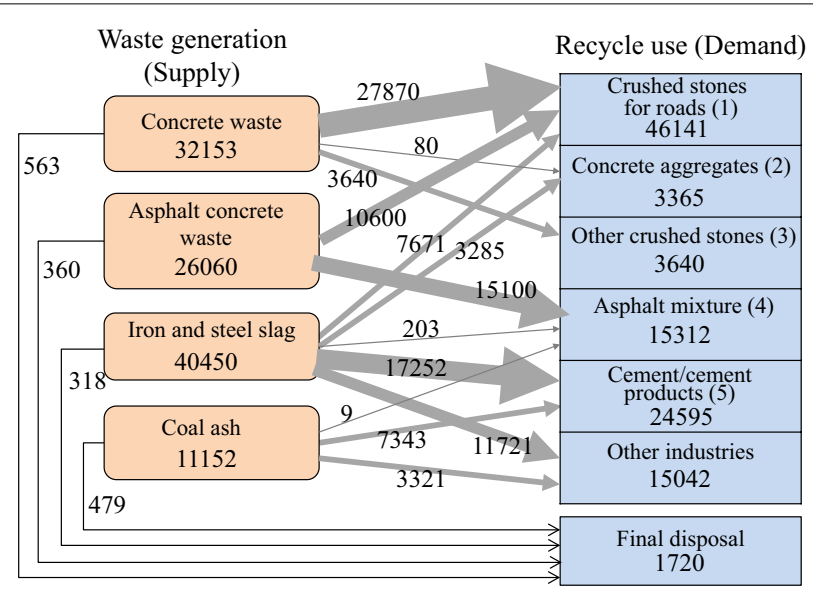

(unit: 1000 ton)

Fig. 3 Material flows of non-metallic mineral wastes in 2005 


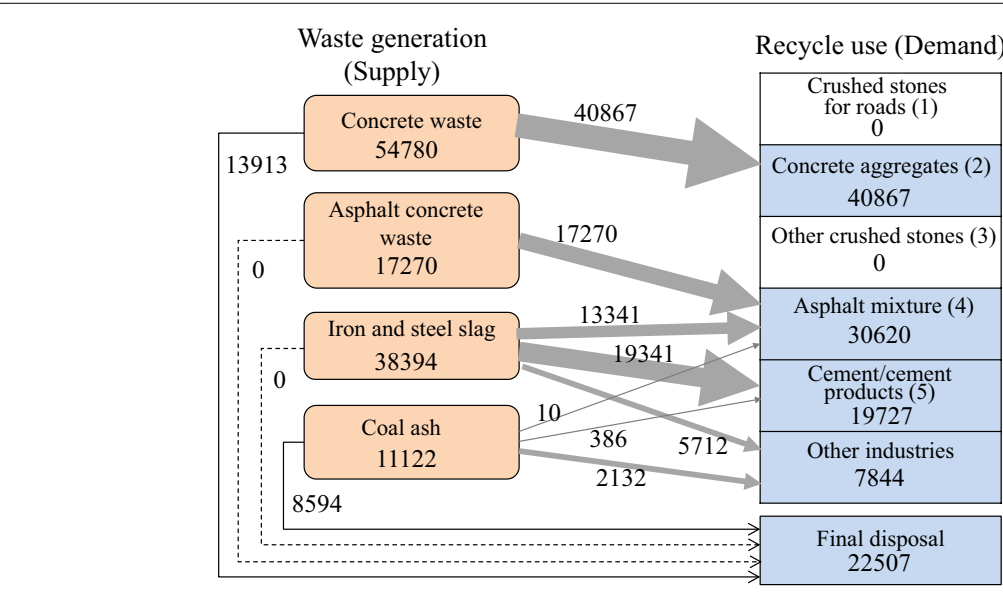

(unit: 1000 ton)

Fig. 4 Material flows of non-metallic mineral wastes in 2030 (BAU scenario)

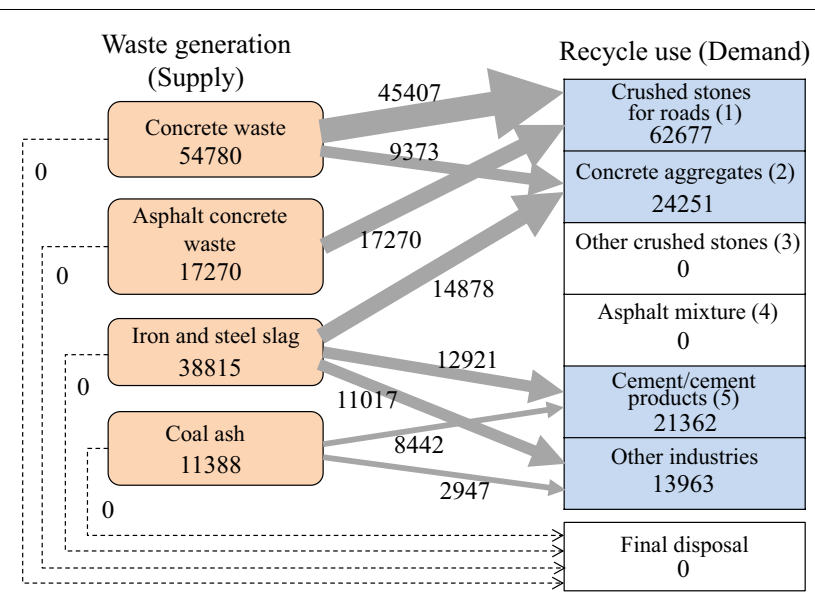

(unit: 1000 ton)

Fig. 5 Material flows of non-metallic mineral wastes in 2030 (zero emission scenario)

Focusing on the BAU scenario in Fig. 4, the total final disposal of non-metallic mineral wastes in 2030 drastically increases to 22,507 thousand tons from 1720 thousand tons in 2005. Although industries can achieve zero emissions of asphalt concrete waste and iron and steel slag, even under the maximization of their value added, the final disposal of concrete waste and coal ash increases to approximately 25 times and 18 times, respectively, compared to the values for 2005. As shown in Fig. 4, non-metallic mineral wastes are not recycled as crushed stones at all if the related industries aim at maximization of their value added.

Figure 5 shows a material flow describing the minimization of final disposal in 2030. The industries achieve zero emission in all non-metallic mineral wastes. In the zero emission scenario, wastes recycled as crushed stone for roads and concrete aggregate increase, but wastes for other uses decrease, compared to the values for 2005 . 
Specifically, the amount of input to other crushed stone and asphalt mixture is zero. Concrete waste is not recycled as other crushed stone in these two scenarios.

\subsection{Value added brought about by non-metallic mineral wastes in $\mathbf{2 0 3 0}$}

Next, we focus on the effect on the economy brought about by the change in material flow from 2005 to 2030. Table 5 shows value added in 2005 and 2030 in the two scenarios and Fig. 6 shows the ratio of change from 2005.

Focusing on the BAU scenario, compared to values for 2005, crushed stone for roads and asphalt mixture drastically increase in the BAU scenario, while other crushed stones fall to zero. The zero value in the sector means that domestic production is completely stopped and demand is satisfied by imports. Other sectors do not largely change from 2005, except for an increase in cement/cement products and a decrease in construction.

On the other hand, in the zero emission scenario, the volumes of value added are smaller than in 2005 or at approximately the same level, except for the increase of

Table 5 Value added in industries related to non-metallic mineral wastes (billion yen)

\begin{tabular}{llll}
\hline & 2005 & 2030 (BAU scenario) & $\begin{array}{l}\text { 2030 (zero emission } \\
\text { scenario) }\end{array}$ \\
\hline 1 Crushed stones for roads & 111 & 289 & 89 \\
2 Concrete aggregate & 61 & 60 & 74 \\
3 Other crushed stones & 76 & 0 & 72 \\
4 Asphalt mixture & 235 & 614 & 74 \\
5 Cement/cement products & 1271 & 1587 & 853 \\
6 Pig iron/crude steel & 1808 & 1716 & 1734 \\
7 Other iron and steel & 4232 & 4053 & 4091 \\
8 Construction & 29,185 & 22,432 & 22,243 \\
9 Electric power, gas supply, and steam and hot water & 8129 & 8271 & 8323 \\
$\quad$ supply & & & 37,554 \\
Total industries related to non-metallic mineral wastes & 45,109 & 39,021 & \\
\hline
\end{tabular}

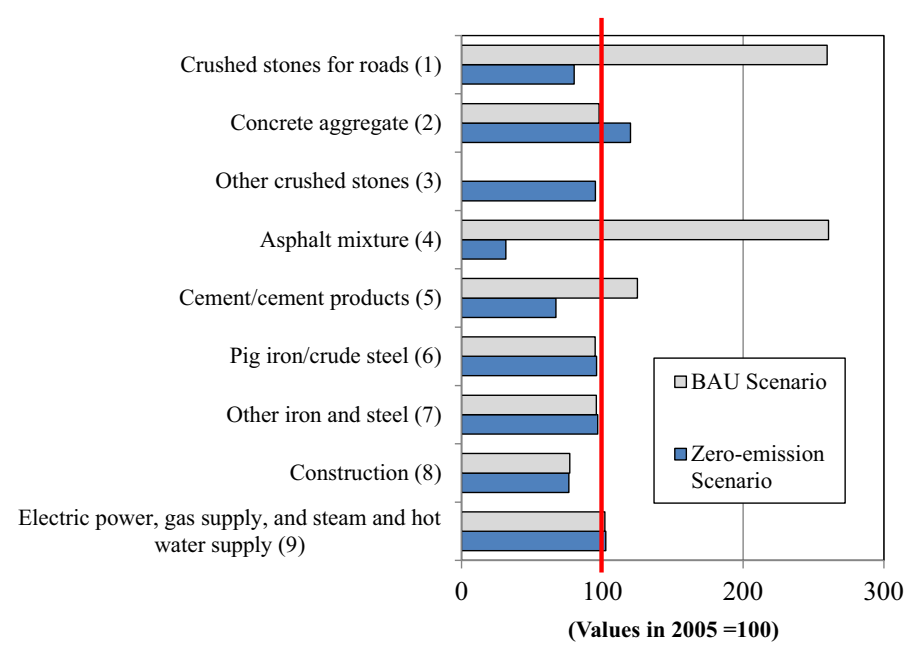

Fig. 6 Change in value added from 2005 
concrete aggregate. Furthermore, asphalt mixture and cement/cement products are largely decreased in contrast to the BAU scenario.

The value added of crushed stone for roads, other crushed stones, asphalt mixture, and cement/cement production are largely different between the two scenarios, while that of the other industries is approximately at the same level. The total value added in industries related to non-metallic mineral wastes decreases from 2005 in both scenarios because of the decline in final demand for construction and the related industries, as shown in Table 4. The total value added in the BAU scenario (39,021 billion yen), aiming at maximizing value added, is larger than that in the zero emission scenario $(37,554$ billion yen). However, the difference is only $3.76 \%$.

\section{Discussion and conclusion}

This paper, shedding light on the increase in generation of non-metallic mineral wastes and decrease in demand for construction, investigates the material flow resulting from and the economic influence of changes in the supply and demand for wastes, focusing on the period from the near future to 2030. Specifically, we construct an IO table for the analysis of non-metallic mineral wastes to identify monetary and material flows between industries related to the supply and demand for non-metallic mineral wastes. Based on the constructed IO table, we predict the material flow and value added brought about by non-metallic mineral wastes in 2030 in the BAU and the zero emission scenarios by developing a linear programming model.

In the BAU scenario, the total final disposal of non-metallic mineral wastes in 2030 drastically increases to 22,507 thousand tons from 1720 thousand tons in 2005, and total value added in the related industries is 390,212 billion yen. On the other hand, the zero emission scenario achieves zero emission in final disposal and obtains a value added of 37,554 billion yen.

This result implies that if the policy for non-metallic mineral waste management is thoroughly carried out in the future, zero emission can be achieved at the small cost of a $3.76 \%$ decrease in the value added. Otherwise, the final disposal might increase 13 times that of 2005. A drastic increase of final disposal waste leads to the shortage of landfill and generates huge social costs, including not only private costs, as the disposal cost, but also external costs, such as environmental contamination. Such a social cost would be much larger than a decrease by $3.76 \%$ in the value added. Focusing on the result, we can suggest the zero emission scenario and encourage waste policies to minimize final disposal of non-metallic mineral wastes.

Furthermore, our analyses enable us to discuss policy implications by materials and industries.

Our analyses show that zero emission can be achieved in asphalt concrete waste and iron and steel slag, even in the BAU scenario. This implies that it is effective for future waste management to stress on recycling concrete waste and coal ash from the viewpoint of material flow, while the remaining wastes are expected to voluntarily decrease their final disposal in the future.

Our analyses also clarify the industries in which value added significantly changes between the two scenarios and two periods. In the discussion on waste policies, it is important to pay attention to large differences between the two scenarios. The zero 
emission scenario largely decreases the value added in crushed stones for roads, asphalt mixture, and cement/cement products, compared to the BAU scenario. It is expected that these industries will suffer from economic declines caused by aiming at zero emission in the zero emission scenario, while they are expected to achieve economic growth after 2005 in the BAU scenario. Therefore, we can conclude that it is necessary for these industries to cope with the negative economic influence caused by the enforcement of waste reduction policies for final disposal.

On the other hand, the zero emission scenario increases the value added in concrete aggregate and other crushed stones, compared to the BAU scenario. The result implies that the reduction policies contribute to further economic growth in concrete aggregate because its value added in the zero emission scenario is larger than that in 2005. Furthermore, the reduction policies also contribute to sustaining the scale of the business in other crushed stones; otherwise, the production is completely stopped.

Our approach is expected to be widely applicable to other countries, which will face a phenomenon similar to Japan, and be further developed by considering the change in production technology for material input and waste generation, which was not examined in this study.

\section{Authors' contributions}

$\mathrm{HN}$ designed the first version of analytical framework and compiled the dataset with respect to material flow in nonmetallic mineral wastes. He was mainly in charge of Sects. 1, 2.1, and 3.1. RH largely modified the first version. He was mainly in charge of the remaining sections and subsections and is responsible for all parts of the study. TS proposed the outline and the aim in the study and totally checked the manuscript. All authors read and approved the final manuscript.

\section{Author details}

${ }^{1}$ Faculty of Urban Management, Fukuyama City University, 2-19-1, Minatomachi, Fukuyama, Hiroshima 721-0964, Japan. ${ }^{2}$ Department of Urban and Environmental Engineering, Faculty of Engineering, Kyushu University, 744, Moto-Oka, Nishi-ku, Fukuoka 819-0395, Japan.

\section{Acknowledgements}

The first version of this study was presented at the 24th International Input-Output Conference, held in Seoul, Korea, from 4th to 8th July 2016. The authors are grateful to editors and anonymous referees for their useful comments and suggestions for revising the paper.

\section{Competing interests}

The authors declare that they have no competing interests.

\section{Availability of data and materials}

Not applicable.

\section{Consent for publication}

Both the authors have consent to publish this manuscript with Journal of Economic Structure.

\section{Ethics approval and consent to participate}

Not applicable.

Funding

This paper is not sponsored by any funding.

\section{Publisher's Note}

Springer Nature remains neutral with regard to jurisdictional claims in published maps and institutional affiliations.

Received: 21 December 2016 Accepted: 14 December 2017

Published online: 27 December 2017

\section{References}

Bullard IIICW, Herendeen RA (1975) The energy cost of goods and services. Energy Policy 3(4):268-278

Duchin F (1990) The conversion of biological materials and waste to useful products. Struct Change Econ Dyn 1:243-262 Gnoni MG, Mummolo G, Ranieri L (2008) A mixed integer linear programming model for optimisation of organics management in an integrated solid waste system. J Environ Planning Manage 51(6):833-845 
Guan D, Hubacek K (2008) A new and integrated hydro-economic accounting and analytical framework for water resources: a case study for North China. J Environ Manage 88:1300-1313

Hashimoto S, Tanikawa H, Moriguchi Y (2009) Framework for estimating potential wastes and secondary resources accumulated within an economy-a case study of construction minerals in Japan. Waste Manag 29(11):2859-2866

Kagawa S (2005) Inter-industry analysis, consumption structure, and the household waste production structure. Econ Syst Res 17(4):409-423

Kagawa S, Nakamura S, Inamura H, Yamada M (2007) Measuring spatial repercussion effects of regional waste management. Resour Conserv Recycl 51:141-174

Kondo Y, Nakamura S (2005) Waste input-output linear programming model with its application to eco-efficiency analysis. Econ Syst Res 17(4):393-408

Leontief W (1970) Environmental repercussions and the economic structure: an input-output approach. Rev Econ Stat 52(3):262-271

Miller RE, Blair PD (2009) Input-output analysis: foundation and extensions, 2nd edn. Prentice-Hall, Englewood Cliffs, NJ

Ministry of Economy, Trade and Industry (2005) Yearbook of Crushed Stone Statistics 2005. Ministry of Economy, Trade and Industry, Japan

Ministry of the Environment (2002) Quality of the environment in Japan 2002. Ministry of the Environment, Japan

Ministry of the Environment (2015) Annual report on the Environment, the sound material-cycle society, and biodiversity in Japan 2015. Ministry of the Environment, Japan

Nakamura S, Kondo Y (2002) Input-output analysis of waste management. J Ind Ecol 6:39-63

Nippon Slag Association (2005) Iron and steel slag 2005. Nippon Slag Association, Japan

Research Institute of Construction and Economy (2016) Construction Economy Report No. 67. Research Institute of Construction and Economy, Japan

Reynolds CJ, Piantadosi J, Boland J (2014) A waste supply-use analysis of Australian waste flows. J Econ Struct 3:5

Song J, Yang W, Li Z, Higano Y, Wang X (2016) Discovering the energy, economic and environmental potentials of urban wastes: a input-output model for a metropolis case. Energy Convers Manag 114:168-179

Tsukui M, Kagawa S, Kondo Y (2015) Measuring the waste footprint of cities in Japan: an interregional waste input-output analysis. J Econ Struct 4:18

Zhu S, Huang GH (2011) SLFP: a stochastic linear fractional programming approach for sustainable waste management. Waste Manag 31:2612-2619

\section{Submit your manuscript to a SpringerOpen ${ }^{\circ}$ journal and benefit from:}

- Convenient online submission

- Rigorous peer review

- Open access: articles freely available online

- High visibility within the field

- Retaining the copyright to your article

Submit your next manuscript at $\boldsymbol{s p r i n g e r o p e n . c o m ~}$ 